\title{
Power and Plenty: Trade, War and the World Economy in the Second Millennium
}

\author{
Ronald Findlay and Kevin H. O’Rourke
}

\author{
TEP Working Paper No. 0107
}

February 2007

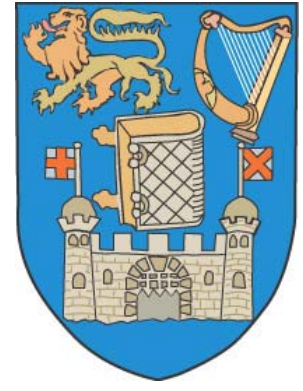

Trinity Economics Papers

Department of Economics

Trinity College Dublin 
Power and Plenty: Trade, War and the World Economy in the Second Millennium (Preface)

\author{
Ronald Findlay (Department of Economics, Columbia University) \\ and
}

Kevin H. O’Rourke (Department of Economics and IIIS, Trinity College Dublin)

February 2007

\begin{abstract}
This book provides the first systematic, integrated, analytical account of the evolution of the international economy during the last millennium.It emphasizes the two-way interaction between trade and geopolitics, and the importance of such interactions for world economic development.
\end{abstract}




\section{PREFACE}

This book was written in the belief that you cannot make sense of today's world economy, or indeed of the world more generally, without understanding the history that produced it. Contemporary 'globalization', and its economic and political consequences, has not arisen out of a vacuum, but from a worldwide process of uneven economic development that has been centuries, if not millennia, in the making. In turn, this process has been critically shaped by the changing ways in which the various world regions have interacted with each other, not only through trade, migration and investment, but also politically and culturally, over time. Understanding this two-way interaction between the pattern and evolution of inter-regional trade, on the one hand, and long-term global economic and political developments on the other, is the main purpose of this volume.

As is the case with many books, this one has been written for the primary benefit of the authors. Countless economic histories of countries or regions have already been written, and there is now a rapidly growing literature on 'world history', and indeed on 'world economic history'. There is also a more specialized, but still immense, literature on the history of international trade, with individual authors typically focusing on particular regions or time periods. What both of us found, however, when preparing lectures on the long run history of world trade, or writing research papers on the subject, is that there was no one place that we could turn to for answers to the questions that we, as economists, would ask about the subject. Instead, we have had to become familiar although no doubt we remain insufficiently so - with a vast and highly specialized scholarly literature, and have found ourselves on numerous occasions plowing through the same sources looking for the odd nugget of information that was relevant for our 
purposes. In this manner, we gradually became independently convinced of the need for a single book that would provide as comprehensive and integrated an overview as possible of the history of world trade during the second millennium.

Even if we consider such an apparently specific and familiar a subject as the spice trade, for example, we find that there is no single authoritative account of it available in the existing literature. The reasons why this is so are quite obvious. The spices were produced in the islands of the Indonesian archipelago, transported across the Indian Ocean by Persians, Arabs, Gujaratis, Portuguese, Dutchmen and sundry others to the Red Sea or the Persian Gulf, or around the Cape of Good Hope, taxed by Abbasids, Fatimids, Mamluks, Safavids and other Middle Eastern regimes, distributed further west and north by Venetians or Genoese, before being purchased as far west as England and France, usually with silver that then had to wind its way back again to the Moluccas before the circuit was closed. And this is only to consider spice flows to Europe, when flows to China and other Asian markets were much more important during most of history. No single historian, not even a Fernand Braudel, could command all the specialized knowledge and skills necessary to cover the entire stretch of space and time involved; and this is only one of many topics that we would like our history of world trade to cover. Providing such a book thus requires breaking free of the twin tyrannies of temporal and spatial parochialism, which is undoubtedly a risky venture.

There have been other world economic histories written in the recent past, but while we have learned much from them, none of them quite provided what we were looking for. Rondo Cameron's (1989) Concise Economic History of the World: from Paleolithic Times to the Present covers an even longer time span than our mere 
millennium. However, neither he nor Greg Clark (2007) provides the sharp focus on trade and other contacts between the various world regions that is the concern of the present work. Janet Abu-Lughod's (1989) highly influential Before European Hegemony: the World-System $A D$ 1250-1350, on the other hand, is concerned with exactly the sort of interactive relationships between the different segments of the world economy that we consider here, but is temporally confined to a single, albeit crucial century, the period of the Pax Mongolica. David Landes (1998) tells us in his Preface that his aim is to "trace and understand the main stream of economic advance and modernization”, which he locates firmly in Europe. While we will also of necessity be concerned with the process of economic growth, our emphasis is more on the pattern and structure of trade, on geopolitical evolution over time, and on the shifting balances of world primacy over the past thousand years.

As evidenced by the very title of his stimulating contribution, Eric Jones’ (2003) The European Miracle is also Eurocentric in its orientation. Jones starts at about the time of the Discoveries, taking as his units of comparison the European system of competing nation-states and the non-European empires of the Islamic Ottomans and Mughals, and the Manchu Qing Dynasty. The rise of Europe is one of the major themes of this book, as it is of his, but we cover a longer time-span than does Jones, and our units are the seven regions defined in Chapter 1, rather than the European states and three Asian empires he considers. Jones has been the target of what he calls the 'California School' of Sinocentric historians, in particular Kenneth Pomeranz (2000) and R. Bin Wong (1997), as well as Andre Gunder Frank (1998). We hope to convince our readers that, like Ulysses bound to the mast, we manage to avoid both the Scylla of Eurocentrism and the 
Charybdis of Sinocentrism in our account of how all seven regions, and the rest of the world besides, have contributed to the interactive emergence of the modern world economy, even though not necessarily to the same degree.

Thus we ourselves have had to laboriously piece together what is still a very rudimentary and inadequate account of trade during the last millennium. There are of course many specialists on each aspect of this subject whose knowledge vastly exceeds ours on their specialty, but we hope that we can at least lighten the labor of the many who might desire, as we did, an overview of this subject as a whole. Furthermore, the history of world trade is only one aspect of the task that we have had to undertake. A feature of the book that may strike some economists as odd or surprising, but will seem entirely commonplace to historians, is its sustained emphasis on conflict, violence and geopolitics. When economics students are first exposed to the study of international trade, they are asked to contemplate two countries, A and B, who have each been endowed with a certain amount of the various factors of production - land, labor, capital and so on - as well as with a given technology which translates those endowments into consumption goods, together with a set of preferences over these goods. The two countries then trade with each other, or not as the case may be, and the consequences of trade are derived for consumers and producers alike. If time is brought into the theory at all, and usually it isn't, this typically takes the form of allowing countries to gradually accumulate capital, breed new workers, or become better educated as a result of the voluntary decisions of rational, free individuals. The summit of unpleasantness attainable in such models is the use of tariffs, quotas and other trade policy instruments that will benefit some individuals 
or groups (and possibly nations), but lower the utility of other domestic or foreign residents.

If only life were like this. As we point out below, the greatest expansions of world trade have tended to come, not from the bloodless tâtonnement of some fictional Walrasian auctioneer, but from the barrel of a Maxim gun, the edge of a scimitar, or the ferocity of nomadic horsemen. When trade required more workers, parental choices regarding quality/quantity tradeoffs could often safely be ignored, since workers could always be enslaved. When trade required more profits, these could be earned via plunder or violently imposed monopolies. For much of our period the pattern of trade can only be understood as being the outcome of some military or political equilibrium between contending powers. The dependence of trade on war and peace eventually became so obvious to us that it is reflected in the title of this volume.

Politics thus determined trade, but trade also helped to determine politics, by influencing the capacities and the incentives facing states. The mutual dependence of Power and Plenty, so well evoked by Jacob Viner (1948), will thus be a key feature of this book. While economists have traditionally stressed the advantages of peaceful voluntary exchange, we should not forget that the use of force involves the allocation of scarce resources as well, and imposes costs and benefits both on those who use it, and on those against whom it is used, as well as on third parties. It is therefore as much subject to the application of economic analysis, "the study of the relationship between ends and scarce means that have alternative uses” in the famous definition of Lionel Robbins, as any other sphere of human activity. 
If all this may appear to have been less true over the course of the last two centuries, this is because of the overwhelming influence of the Industrial Revolution on all subsequent economic history. The nineteenth century globalization that followed this breakthrough was unprecedented in many ways, and as we will see perhaps its most clearly distinguishing feature was its largely technological underpinnings (although even in this period imperialism still had an important role to play, and was itself facilitated in many ways by the new technology). The new technologies not only brought markets closer together than ever before, but opened up enormous income gaps between regions that remain with us today, and produced a stark division of labor between a manufacturing core and a primary-producing periphery. The big questions ever since then have been: How can developing countries catch up with the core? Should they do so by exploiting their natural resource advantages, as was successfully tried in the nineteenth century, or does this leave them excessively vulnerable to fickle international markets, as the interwar experience might suggest? Should they decouple themselves from international markets as many did after 1945, or reintegrate with them as they have done over the past two decades? These questions, and related ones such as how the West should accommodate the rise of India and China, have only arisen because of the asymmetries created by the Industrial Revolution, and are thus fundamentally historical in nature.

The Industrial Revolution, in turn, can only be understood as the outcome of a historical process with multiple causes stretching well back into the medieval period, and in which international movements of commodities, warriors, microbes and technologies all played a leading role. Purely domestic accounts of the Rise of the West, emphasizing 
western institutions, cultural attributes or endowments are hopelessly inadequate, since they ignore the vast web of inter-relationships between Western Europe and the rest of the world that had been spun over the course of many centuries, and were crucially important for the breakthrough to modern economic growth. We are of course not the first to have argued this, but historians promoting such an international perspective have usually been Marxists, which we are not. Like most mainstream economists, we view inventiveness and incentives, rather than sheer accumulation, 'primitive' or otherwise, as being at the heart of growth, but this does not imply that European overseas expansion should be written off as irrelevant. Plunder may not have directly fuelled the Industrial Revolution, but mercantilism and imperialism were an important part of the global context within which it occurred, expanding markets and ensuring the supply of raw materials. Violence thus undoubtedly mattered, in shaping the environment within which the conventional economic forces of supply and demand operated.

In this manner, many of today's key inter-regional tensions can be traced back to earlier interactions between the world's main regions. In seeking to understand this history, economists need to think seriously about another subject they have too often neglected, namely geography. By 'geography', we do not mean the highly stylized models that pass for 'economic geography' today, in which ex ante indistinguishable regions symmetrically situated on a featureless plane, straight line, sphere or hexagon interact with each other and become different ex post, with small random events having impacts that are amplified and made permanent through the operation of increasing returns to scale. When we say geography, we mean geography: mountains, rivers and all. If Genghis Khan had been born in New Zealand, he would have left no traces on world 
history. The Irish might have enjoyed holding the rest of Europe to ransom by controlling access to Southeast Asian spices, but never had the opportunities which geography afforded the rulers of Egypt. A European seeking direct access to India might well head westward and stumble across the Americas, but no Chinese sailor would have been foolish enough to seek an eastern passage to Arabia. Many possible outcomes in world history were ruled out ex ante, not just ex post.

The three great 'world-historical' events of the Second Millennium, in our account, are the ‘Black Death’ of the fourteenth century and the differing responses to it, the 'discovery' and incorporation of the New World into that of the Old at the turn of the sixteenth century, and the Industrial Revolution at the turn of the nineteenth. As we hope to demonstrate conclusively, no single region was solely responsible for any one of these three transformational episodes, let alone all three. The first resulted from the Pax Mongolica, established by the nomads of Central Asia but consolidated and actively participated in by all of the other six. Western Europeans were the first Eurasians to sail to the New World, but it was Africans, against their will, who produced the commodities that it exported to the Old. The Industrial Revolution occurred within Western Europe, and more specifically in Britain, but the essential raw material that its leading sector required was produced by Africans in the Americas, and the final products were sold in markets around the entire world. The world economy continues to evolve, with the lead of Western Europe and its various overseas offshoots clearly eroding, as East, South and Southeast Asia all expand much faster after previous centuries of relative stagnation.

Before asking the reader to plunge into a thousand years of history, it behooves us to provide a brief guide to the terrain that lies ahead. We begin in the first chapter with a 
consideration of basic methodological issues, and the delineation of the seven 'worldregions' into which we divide the Eurasian landmass and the southern littoral of the Mediterranean at the beginning of the second millennium. These regions are Western Europe, Eastern Europe, the Islamic World of the Middle East and North Africa, Central Asia, South Asia, Southeast Asia and East Asia. Since all seven are defined not just by geography, but by culture and political history as well, we provide a brief account of what we consider to have been the defining characteristics of each. Thus we choose the division between western Roman Catholicism and eastern Orthodoxy to demarcate Western from Eastern Europe, rather than some geographical feature. The fall of Constantinople to the Ottoman Turks, in our scheme, transferred the remnants of the former Byzantine Empire to the Islamic World. In the case of Indonesia and the Malay world, however, we retain the geographic designation of these societies as Southeast Asian, along with their Buddhist neighbors, rather than shifting them into the Islamic World following their conversion to Islam, since we believe that they still had more in common with these neighbors than with Egyptians or Syrians.

The second chapter analyzes the trading and other relationships between these seven regions and an eighth, Sub-Saharan Africa, at the turn of the second millennium. The reader might be surprised to learn that the only region in sustained direct contact with all the others at this time was the Islamic World, then undergoing its Golden Age under the Abbasid, Fatimid and Umayyad Caliphates based in Baghdad, Cairo and Cordoba, while the one with the least contact with the others was Western Europe. The third chapter is a broad analytical survey of the evolution of the world economy from 1000 to 1500 . The key events on which we focus in this chapter are the forging of the 
Pax Mongolica that knitted together most of the Eurasian landmass under the aegis of the Mongol Empire, and stimulated long-distance trade from the Atlantic to the Sea of Japan; the devastating consequences of the Black Death, itself unleashed by the formation of what has been called a "microbian common market" as a result of the Mongol conquests; and the subsequent expansion of population, output and prices across the world, particularly in Western Europe and Southeast Asia.

This sets the stage for the launching of the Iberian voyages of discovery and their momentous consequences for the New World, Africa and Asia, dealt with in the fourth chapter, covering the period from about 1500 to 1650. A key economic consequence of Columbus that we will be exploring at length is the worldwide trade in silver that emerged during the sixteenth century. The fifth chapter focuses first on the long struggle for hegemony in the emerging world economy between the Dutch Republic, Great Britain and France during the Age of Mercantilism, and then on the hardly less momentous overland expansions, from opposite ends of Central Asia, of the Czarist empire of the Romanovs and the Chinese empire of the Manchu Qing Dynasty. One major theme of this chapter is the extent to which Asians were not just passive actors during this period, but adopted new military technologies, with similar political effects to those experienced in Europe; another is the mercantilist economic policies pursued by the leading states of the day.

The sixth chapter interrupts the historical narrative, to take a close look at the breakthrough to modern economic growth which occurred in northwestern Europe, and more particularly Great Britain, at the turn of the nineteenth century. The Industrial Revolution merits a separate chapter, since it is the fulcrum around which the rest of the 
book turns. On the one hand, it set in motion economic forces that determined the future course of international trade, down to our own day; on the other, it was itself an outcome of the political and economic trends that preceded it. Thus we do not see the Industrial Revolution as springing up suddenly, like "Athena fully armed from the brow of Zeus," purely as a result of the creative imaginations of a group of inventors in the north of England in the late eighteenth and early nineteenth centuries. As we hope to be able to convince the reader, we see it instead as the culmination of a long historical process involving the interaction of all the world's regions through trade and the transfer of technology, as well as the use of armed force. This is not to deny the vital contribution of Great Britain, and more broadly Western Europe, but to provide a consistent and coherent explanation of why this event was so transformational in nature, rather than evanescent, as had been all the earlier "efflorescenses” (Goldstone 2002) in the history of the world economy that we describe.

On one level, the economic history of the past two centuries can as already noted be viewed as the working out of the consequences of the Industrial Revolution: a 'Great Divergence' in income levels between regions, as the new technologies diffused only gradually across the globe; a 'Great Specialization' between an industrial core and a primary-producing periphery; consequent pressures to protect agriculture in the core, and manufacturing in the periphery; and finally, a gradual unwinding of these trends as the Industrial Revolution spread to encompass an ever-increasing proportion of the globe. Indeed, we are still experiencing these entirely predictable consequences of events which took place in northern England two centuries ago. However, the evolution of these trends was not smooth, but was profoundly marked by the political consequences of three major 
world wars: the French and Napoleonic wars that ended the Age of Mercantilism; World War I; and World War II. Warfare thus continued to exert a profound and long-lasting effect on the evolution of the international economy, and this is reflected in the structure of the book, with Chapters 7 through 9 each beginning with an account of the relevant conflict, and then proceeding to trace out its short and long run consequences.

Chapter 7 resumes our narrative, and focuses on the 'long nineteenth century' from 1815 to 1914. The era was marked politically by the Pax Britannica and European imperialism, and economically by the consequences of the new steam technology of the Industrial Revolution, embodied in the railroad and the steamship. It was early in this period that a new sort of globalization, manifested by a significant narrowing of intercontinental price gaps for bulk commodities between points of origin and destination, occurred pervasively around the world as a result of dramatic declines in transport costs. It is also the period when the 'Great Specialization' emerged, as a result of which the industrialized countries of Western Europe, eventually to be joined by the United States and Japan, exported manufactured goods to Asia, Africa, Australia and Latin America in exchange for primary foodstuffs and raw materials, with Europe also exporting capital to all these regions, and people to the Americas and Australia. The end of this period was marked by the beginnings of a 'backlash’ against globalization, with the rising industrial powers of Germany and the United States, the food-importing countries of Continental Europe, the Latin American republics and the settler dominions of the British Empire all raising tariffs; while the New World starting displaying a reluctance to remain open to mass immigration. This first ‘Golden Age of Globalization’ was of course brought to a tragic and abrupt end by the outbreak of the First World War. 
The interwar years from 1918 to 1939, covered in Chapter 8, were dominated politically and economically by the aftermath of this catastrophe. While the 1920s saw an attempt to reconstruct the pre-war international economy, which enjoyed only partial success, the 1930s were marked by the devastating consequences of the Great Depression, and the resulting retreat from globalization. The Second World War and its aftermath are the subject of Chapter 9, the key political events being the establishment of the Pax Americana and the associated framework of multilateral international institutions set up under its aegis; the political transformations wrought first by the spread of Communism and then by its collapse; and the sweeping decolonization of areas in the Third World that had become imperial possessions of the European powers. We stress that the combined effect of these trends was to further disintegrate the world economy, with OECD liberalization constituting a regional exception to this general rule, until some time in the 1970s or 1980s. It was only then that Latin America, Asia and Africa, where the bulk of humanity reside, started to open up to trade and investment with the rest of the world. Economically, the late twentieth century was to a large extent dominated by the attempt of newly independent countries to industrialize through policies of 'import substitution'. However, the period also saw the unprecedented expansion of world output and trade as a result of trade liberalization and growth in the industrial countries, and technological diffusion to 'newly industrializing countries'. This eventually led to the rapid growth of manufactured exports from these countries, particularly China and India, and to the beginnings of a narrowing of the huge per capita income gaps that have separated these once prosperous regions from Western Europe since the Industrial Revolution, and probably even before. The tenth and final chapter 
draws together some of the lessons which our extended survey has taught us, and which we believe may still be relevant at the start of the twenty first century.

The reader will have noticed that our successive eras in the evolution of the world economy, and not just those covered by Chapters 7 through 9, have been demarcated mostly by the outbreaks of major wars or imperial expansions. Each era can be seen as one in which trade is conducted within a geopolitical framework established by the previous major war or conflict, that is in turn altered by the outbreak of the next war, setting the stage for the next trade epoch and so on. It is natural to suspect that the accumulating economic and geopolitical tensions unleashed in the course of each period of peace, prosperity and trade culminate in successive rounds of conflict, so that wars, rather than being exogenous shocks to the world system, have been inherent in its very nature as it has evolved over the past millennium. For the most part this process will, we hope, become clear from our narrative, although we confess that the First World War still appears as somewhat of a diabolus ex machina in our account. There is of course no shortage of authorities who have argued that the way in which the late nineteenth century world economy operated helps explain the eruption of World War I, but the causes of this disaster remain controversial. "Had we but world enough, and time”, we might have done better, but there are only so many cans of worms that one can open in the course of writing a book, and this is one can that we have decided to leave closed.

Economics is often accused of being an imperialistic discipline, and plunder was an essential feature of many of the empires that we will be considering below. We have enthusiastically followed the example of the conquistadores in this respect, unscrupulously plundering the knowledge that has been laboriously produced by 
generations of historians and economists before us. Unlike the conquistadores, however, we have done so in the hopes of being civilized by the natives, rather than the reverse. There is a lot in this book, therefore, that will be entirely unremarkable to any moderately well trained historian, but which we hope will be of interest in its present form not just to economists, economic historians, political scientists, sociologists and anthropologists, but to the broad community of all those with a serious interest in globalization, and who like us want to better understand the origins of the international economy of the early twenty first century. If the way that we approach the evidence as economists adds some value to historical debates, then so much the better.

Though our discipline strictly informs and shapes our argument at every point, we have not felt it necessary to burden our text with sustained stretches of formal mathematical or quantitative analysis, though we frequently refer the reader to works, including some of our own, that use such methods to reach and sustain conclusions of interest to the general reader. Both of us can truthfully say that we know vastly more about the historical evolution of the world economy after writing this book than we did when we began, despite having devoted much of our previous professional lives to the study of it. We hope that we can pass on to the reader at least some of the excitement and understanding that this perhaps all too ambitious project has given us. 


\section{References}

Abu-Lughod, J. L. 1989. Before European Hegemony: The World System AD 1250-1350. New York: Oxford University Press.

Cameron, R. 1989. A Concise Economic History of the World: From Paleolithic Times to the Present. New York: Oxford University Press.

Clark, G. 2007. A Farewell to Alms: A Brief Economic History of the World. Princeton: Princeton University Press.

Frank, A.G. 1998. ReORIENT: Global Economy in the Asian Age. Berkeley: University of California Press.

Goldstone, J.A. 2002. Efflorescences and Economic Growth in World History: Rethinking the "Rise of the West" and the Industrial Revolution. Journal of World History 13: 323-389.

Jones, E.L. 2003. The European Miracle: Environments, Economies and Geopolitics in the History of Europe and Asia, Third Edition. Cambridge: Cambridge University Press.

Landes, D. 1998. The Wealth and Poverty of Nations: Why Some are so Rich and Some are so Poor. New York: W.W. Norton.

Pomeranz, K. 2000. The Great Divergence: China, Europe and the Making of the Modern World Economy. Princeton: Princeton University Press.

Viner, J. 1948. Power Versus Plenty as Objectives of Foreign Policy in the Seventeenth and Eighteenth Centuries. World Politics 1: 1-29.

Wong, R.B. 1997. China Transformed: Historical Change and the Limits of European Experience. Ithaca: Cornell University Press. 